\title{
Evaluation of the effects of various factors on aboveground and belowground biomass storage capacity of Rhododendron ponticum
}

\author{
Evaluación de efectos de diversos factores sobre la capacidad de almacenamiento \\ de biomasa aérea y subterránea de Rhododendron ponticum
}

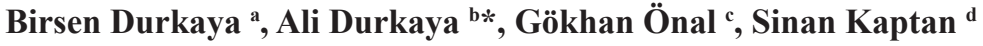 \\ ${ }^{a}$ Bartin University, Faculty of Forestry, Forest Engineering, Department of Forest Management, \\ Ağdacı Country, 74100, Bartın, Turkey. \\ * Corresponding author: ${ }^{\mathrm{b}}$ Bartin University, Faculty of Forestry, Forest Engineering, \\ Department of Forest Management, Ağdacı Country, 74100, Bartın, Turkey, adurkaya@bartin.edu.tr \\ ${ }^{\mathrm{c}}$ General Directorate of Forestry, Ankara, Turkey. \\ ${ }^{\mathrm{d}}$ Bartin University, Faculty of Forestry, Forest Engineering, Department of Forest Management, \\ Ağdac1 Country, 74100, Bartın, Turkey.
}

\begin{abstract}
SUMMARY
Although there is a great potential for Rhododendron ponticum (common rhododendron) to naturally spread throughout the entire Black Sea region of Turkey, there has been no generic biomass study. Therefore, this study was carried out to determine the biomass amounts of common $R$. ponticum populations and how that biomass differs according to certain vegetation and habitat characteristics. Data were obtained from 36 plot areas in the Black Sea region of Turkey: 18 from Giresun and 18 from Bartin. The data were afterwards grouped in terms of altitude, dominant exposure and vegetation height factors, to reveal the change of $R$. ponticum biomass accordingly. The data obtained showed significant variation; therefore, mass values are expressed as mean values. The potential relationship between the afore-mentioned factors and the amounts of biomass was examined by using the analysis of variance. Results showed that the highest biomass amount occurs at 0-500 $\mathrm{m}$ in altitude, with a mean biomass of 40,035 $\mathrm{kg} \mathrm{ha}^{-1}$. Regarding dominant exposure and biomass amounts, the mean biomass of the $R$. ponticum population was found to be $38,185.6 \mathrm{~kg}^{-1}$ in sunny exposure and $35,185 \mathrm{~kg} \mathrm{ha}^{-1}$ in shady exposure. Regarding vegetation height and biomass amounts, 38,820.7 $\mathrm{kg}^{-1} \mathrm{was}^{-1}$ the highest biomass when the vegetation height was 2-2.5 m. Overall however, the analysis of variance for exposure, altitude and mean height of vegetation revealed no significant differences among the groups. It can be concluded that using average values to estimate biomass storage capacities of $R$. ponticum populations is the most reasonable way to proceed at this time.
\end{abstract}

Key words: biomass, Rhododendron ponticum, root/shoot ratio, altitude, exposure, LDMC.

\section{RESUMEN}

Aunque existe gran potencial para que Rhododendron ponticum (rododendro común) se extienda de forma natural por la región del Mar Negro de Turquía, no ha habido ningún estudio genérico de biomasa. Por lo tanto, este estudio se llevó a cabo para determinar las cantidades de biomasa de las poblaciones de $R$. ponticum y cómo esa biomasa difiere de acuerdo con ciertas características de la vegetación y el hábitat. Los datos se obtuvieron de 36 parcelas en la región del Mar Negro de Turquía: 18 de Giresun y 18 de Bartin. Los datos se agruparon según altitud, exposición y altura de la vegetación, para revelar el cambio de la biomasa $R$. ponticum. La relación entre dichos factores y la biomasa se examinó mediante análisis de varianza. El análisis de la varianza para la exposición, la altitud y la altura media de la vegetación no reveló diferencias significativas entre los grupos. Los resultados mostraron tendencia de mayor cantidad de biomasa $\left(40.035 \mathrm{~kg} \mathrm{ha}^{-1}\right)$ a 0-500 m de altitud. Con la exposición se encontró que la biomasa media tendió a ser mayor en condición soleada $\left(38.185,6 \mathrm{~kg} \mathrm{ha}^{-1}\right)$ que sombría $\left(35.185 \mathrm{~kg} \mathrm{ha}^{-1}\right)$. Cuando la altura de la vegetación fue de 2-2,5 m, la biomasa tendió a ser mayor $\left(38.820,7 \mathrm{~kg} \mathrm{ha}^{-1}\right)$. Se puede concluir que el uso de valores promedio para estimar las capacidades de almacenamiento de biomasa de las poblaciones de $R$. ponticum es la forma más razonable de proceder en este momento.

Palabras clave: biomasa, Rhododendron ponticum, relación raíz/tallo, altitud, exposición, LDMC.

\section{INTRODUCTION}

Rhododendron is the largest genus of the Ericaceae family, with approximately 1,200 species (Rotherham 1983).
Their natural habitat spreads from northeastern Asia to the east of North America (Çolak 1997). Rhododendron ponticum L. (common rhododendron), which is a member of this genus, is a species of auxin belt (Aksoy and 
Mayer 1975). Although it is an auxin belt species, R. ponticum spreads over Turkey, Caucasia, Lebanon, England, Ireland, Bulgaria, Spain, central and southern Portugal, Belgium and France. The Black Sea region has the largest distribution of $R$. ponticum (Clay et al. 1992, Çolak 1997).

Although the various Rhododendron species are different in their resistance to environmental stress, $R$. ponticum avoids growing in locations where there is insufficient soil moisture (Cross 1981). However, being a shade-tolerant species is an advantage over its non-shade-tolerant rivals. Even a $90 \%$ canopy cover cannot prevent the penetration of this species into such an area (Gritten 1995).

Rhododendron ponticum is a type of vegetation without an obvious main body. It has a complex branching structure and very dense foliage (Nadezhdina et al. 2004). While it has more sparse foliage and a taller, more spread-out form under canopy cover, it is shorter with more dense foliage in open areas. Under optimal growing conditions, it may grow vertically to heights of 7-8 $\mathrm{m}$ in the eastern Black Sea region, and its diameter can spread over $30-40 \mathrm{~cm}$. It grows in altitudes up to $2,100 \mathrm{~m}$ and is distributed throughout northern Anatolia (Çolak 1997).

It is generally an undesirable species. It constitutes an impediment to the germination and development of the natural plant habitat in forested areas of the Black Sea region. In locations of decreased canopy cover, one finds scrub growth in the Mediterranean region and the Rhododendron spp. in the Black Sea region (Çolak 1997). Rhododendron spp. not only prevent seed from germinating, they also steal the nutrition, light and water from the saplings in their environment (Lei et al. 2006). Furthermore, Rhododendron spp. cover and block light from small saplings in the environment, which leads to their death due to lack of light (Eşen 2000). Additionally, Rhododendron spp. reduce the speed of decomposition in the top layer of soil and cause the formation of acidic humus (Nadezhdina et al. 2004). Lastly, Rhododendron spp. also create a serious impediment for field studies in forestry (Varol and Özel 2005).

Because of the above-mentioned characteristics, Rhododendron spp. are considered an invasive species, which are problematic for commercial forests, where they are not wanted. Most of the studies on Rhododendron spp. were carried out to identify their invasive species and to find a way to deal with them (Gritten 1995, Milne and Abbott 2000, Dehnen-Schmutz et al. 2004). The biomass of Rhododendron spp., however, has caught the attention of many researchers, who have investigated their potential use in manufacturing, especially in the creation of fiber and particleboard. From a technological aspect, Rhododendron spp. were found useful in particleboard production, even though they are not used in the production process due to lack of economic feasibility (Akgül et al. 2012).

Data regarding woody biomass are necessary for understanding facts such as: carbon storage and the carbon cycle, global benefits, determining the yield of vegetation, bioenergy source management and the estimation of amount of flammable material in forest fires (Durkaya et. al. 2016). Because of the international processes and agreements, in which Turkey is participating, Turkey must protect its contribution of forest ecosystems to the carbon cycle and internationally declare its level. The United Nations Framework Convention on Climate Change (UNFCCC) obliges all parties to prepare, publish and periodically update the national inventories, using comparable methods regarding gas emissions, which have a greenhouse effect, forest removal, change in use of forestland and forestry practices according to UN guide practice (Joosten et al. 2004). Before the present study, there was no study performed on the $R$. ponticum regarding its natural distribution area in Turkey, which would allow for the estimation of carbon-storage levels.

To assess the biomass of $R$. ponticum correctly, it is necessary to determine the different factors affecting biomass change. It is known that factors such as average vegetation age and elevational diversity gradient have either positive or negative correlations with biomass storage capacity (Pajtik et al. 2008, Zhang et al. 2009). Dominant exposure and mean height of vegetation are investigated as additional variables because they likely affect the biomass development of $R$. ponticum.

In literature research, no comparative study was found (excluding work done in Artvin at 1,700 m height (Özkaya 2016) of the $R$. ponticum biomass storage by various vegetation and habitat condition characteristics. Primarily, this study will provide practical and useful information on biomass storage data for $R$. ponticum populations. Furthermore, this study draws attention to the uncertainties and difficulties for researchers and practitioners in assessing and measuring $R$. ponticum biomass and the lack of previous studies. One of the main obstacles is the principle of "accurate and exact determination" in biomass reports. The current study will make it possible to understand the differences in biomass capacities and to make better biomass capacity evaluations.

Rhododendron ponticum populations in the Giresun and Bartin regions, where populations of that species are distributed, were investigated in this study. Because of the high $R$. ponticum reserves, the afore-mentioned regions have all the characteristics needed for sampling.

The hypothesis of this study is: there are differences in the distribution of biomass of the $R$. ponticum according to exposure, altitude, mean height and mean age of vegetation. To test this hypothesis, we tried to determine if there is a difference between aboveground and belowground biomass storage of $R$. ponticum, which is distributed throughout the Black Sea region. We also attempted to reveal the variation in the level of biomass storage by certain vegetation and habitat condition characteristics. The objectives in this study are:

- To determine biomass storage capacity of R. ponticum according to sun/shade exposure, altitude, and 
mean height of vegetation by regional comparison (Giresun to Bartin).

- To determine the relationship of mean age with aboveground, belowground, and total amount of biomass.

- To evaluate for statistically significant differences among biomass components by groups and subgroups.

\section{METHODS}

Study area. Bartin and Giresun districts were selected to be study areas, as they are natural distribution areas for this species. Both of these regions host widespread natural $R$. ponticum vegetation and are suitable for specimens having the required characteristics. The Giresun district is located in the east, while the Bartin district is located in the west, both in the Black Sea region (figure 1). There are approximately $500 \mathrm{~km}$ between the two regions.

Climate data. The dominant climate in the study areas is the Black Sea climate type. This type of climate includes abundant rainfall throughout the year, moderately hot summers and mild winters. Since the research areas are near the sea and in low altitude mountain areas, parallel to the shore, the temperature difference along the shore decreases, humidity increases and air mass from the Balkans is in effect.

Annual mean temperature in the Bartin district is $12.9^{\circ} \mathrm{C}$, with the highest average temperature being $42.8^{\circ} \mathrm{C}$ in July and the lowest average temperature being $4.1^{\circ} \mathrm{C}$ in January. Annual precipitation is $1,040.1 \mathrm{~mm}$ on average, with the highest precipitation amount being $181 \mathrm{~mm}$ (in August) and the driest month being April with $40 \mathrm{~mm}$. The relative humidity is an average of $55.6 \%$ annually. The vegetative period lasts for six months. Accordingly, the area's precipi- tation type was found to be rich in humidity and the vegetation cover was found to be an overly humid forest.

The annual mean temperature in the Giresun district is $14.2^{\circ} \mathrm{C}$, with the highest mean temperature being $22.3{ }^{\circ} \mathrm{C}$ in August and the lowest mean temperature being $6.9^{\circ} \mathrm{C}$ in February. The highest level of precipitation occurs in October and November, while the lowest level of precipitation occurs in May and June. The highest monthly precipitation level may exceed $140 \mathrm{~mm}$, while the minimum level does not fall below $60 \mathrm{~mm}$. The annual mean relative humidity is $61 \%$.

Experimental data. At the beginning of this study, the natural factors that had potential to affect the biomass storage capacity of $R$. ponticum vegetation were determined, and the study was designed accordingly. These factors were divided into four groups, and afterwards, the subgroups were established (except for the mean age). The sampling procedure was executed to cover these groups and subgroups, and the data were clustered accordingly. The groups and sub-groups established are listed below:

1. Exposure: Sunny exposure (14 plots), shadowy exposure (22 plots),

2. Altitude (m): 0-500 (12 plots), 501-1,000 (16 plots), 1,001-1,500 (5 plots), 1,501- (3 plots),

3. Mean height of vegetation: up to $1-1.5 \mathrm{~m}$ (5 plots), $1.51-2 \mathrm{~m}$ (12 plots), $2.1-2.5 \mathrm{~m}$ (14 plots), and 2.51-3 m (5 plots),

4. Mean age.

This study was carried out using the data collected from 36 plot areas of $100 \mathrm{~m}^{2}, 18$ areas in each region. In determining the plot areas, the regions in which the $R$. ponticum flora covered $70 \%$ or more of the area were selected first to ensure the standard. To reduce slope-related errors, the

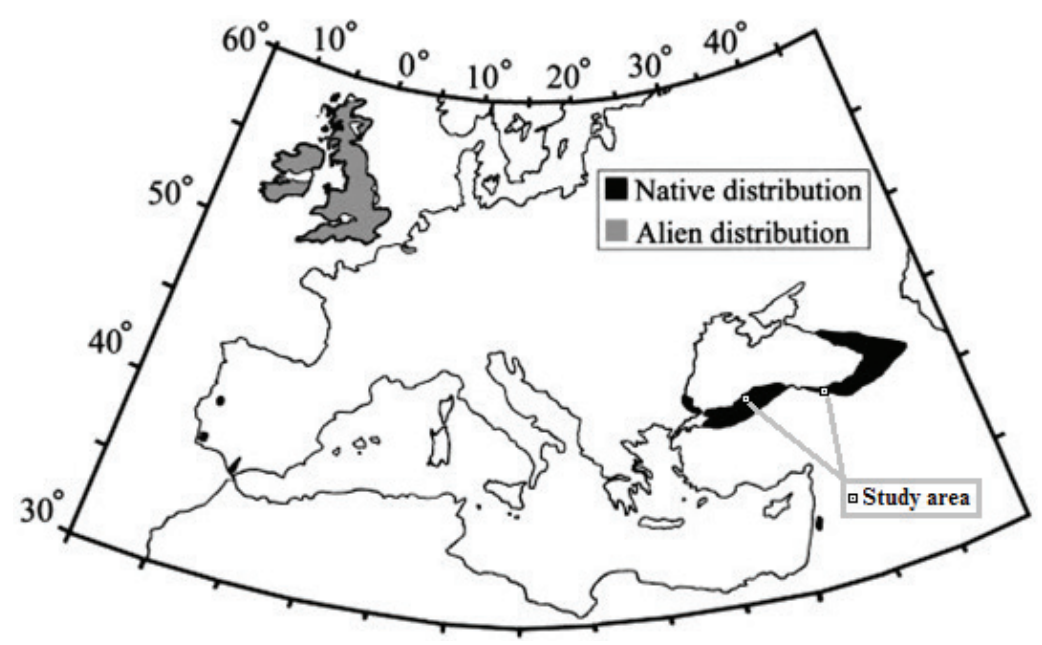

Figure 1. Native and alien distribution of Rhododendron ponticum (Cross 1975) and study areas. Distribución nativa y exótica de Rhododendron ponticum (Cross 1975) y áreas de estudio. 
study commenced on land with 5-10\% slope. The study areas were distributed in accordance with the aim of this study (in dimensions of $10 \mathrm{~m} \times 10 \mathrm{~m}$ ) according to various altitude, exposure and vegetation height levels. Since the factor of slope does not affect the biomass storage capacity of $R$. ponticum vegetation, it was not involved in the experimental design. In studies on sloping lands, the requirement is to determine a correction factor and recalculate the edge lengths to accurately find the limits of sample plots. To prevent possible error and time loss in these calculations, the sampling procedure was executed on lands having up to $10 \%$ slope. In examining the actual statuses of the land plots, only the alive, healthy and robust individual populations were chosen. Summarized data from the temporary plots can be seen in table 1 .

To determine the aboveground biomass, all the individuals within each plot area were clear-cut at ground level, and the branches were weighed. Besides that, the stem sections were taken from 3-5 individuals at the point closest to the soil level to determine the age.

To determine the belowground biomass, the distribution of individuals within the plot areas: at every sampling point, a $2 \mathrm{~m} \times 2 \mathrm{~m}$ section was dug down to the bedrock, and the roots were taken out and weighed. Fine root (thinner than $2 \mathrm{~mm}$ ) sampling was not performed, and they were excluded from assessment.

Samples were taken from every component and fresh weights were measured. To determine the weight of leaves, the sample branches were taken and by separating the leaves, the weights of leaves and branches were measured, and compared to estimate the ratio. Subsequently the samples were taken to the laboratory and completely dried at $65 \pm 3{ }^{\circ} \mathrm{C}$ and their dry weights were found. Using fresh/ dry weight ratios, the fresh weight values were translated into dry weight values. Although the most widely accepted method for determining the moisture content of wood is to dry in an oven at $105^{\circ} \mathrm{C}$, the removal of volatile content at this temperature may lead to errors in estimating moisture content (Granstrom 2003).

The analyses of data obtained from plots of $100 \mathrm{~m}^{2}$ were performed in keeping with the design of the study. According to the study design, to reveal the R. ponticum' biomass, four groups were sampled which were believed to have an effect on the biomass, and were afterward divided into sub-groups. By using the analysis of variance, differences between these sub-groups were established.

To determine the relationship between the obtained data, hypothesis $\mathrm{H}_{1}$ was set first.

$\mathrm{H}_{0}$ : There is no difference between the groups' mean values.

$H_{1:}$ There are differences between the groups' mean values.

To test the hypotheses, the analysis of variance was used in this study. Since the altitude and height levels (the independent variables) consist of four groups, the analysis of variance was preferred (table 2). Even though the "exposure" variable consisted of two groups, the analysis of variance was utilized because the results that a t test would give (the alternative to the analysis of variance) would be the same as it would be for the variables consisting of two groups. The relationship of the age variable to the biomass was analyzed using the regression analysis.

The analysis of variance covers dependent and independent variables. The independent variables are also called "factors". The magnitude of the factor effects on the dependent variables was examined. The dependent variables were categorical, while the independent variables were metric.

In addition to estimating the biomass quantities of the components, leaf dry matter amounts (LDMC) were also determined based on age, altitude levels and exposure. LDMC is the ratio of leaf dry mass to fresh mass, Vaieretti et al. 2007, Zhang et al. 2017).

\section{RESULTS}

One of the potential results anticipated during the study design phase was that there might be a sufficiently reliable relationship between the mean age of vegetation and biomass. The performed analyses showed that even the ages of individuals in the same plot area differed significantly in their biomass, and that the relationship between biomass development and mean age has significant variation. As a natural result of this situation, no relationship could be established using the regression equations between age and biomass (figure 2).

Other results were obtained in accordance with the design of the present study. Since the data were obtained from four different altitude levels, two exposures and four height levels, results are presented in the same order. The results of the analysis by altitude levels are presented below.

To determine if variables vary according to the "altitude" parameter, the analysis of variance produced the following results presented in table 3 . There is no statistically significant difference among the variables, because " $P$ " values were found to be higher than 0.05 . Here, it can be concluded that altitude levels have no effect on the biomass development of $R$. ponticum.

As seen in table 4, it can be stated that the amount of biomass stored by $R$. ponticum insignificantly varied among $0-1,500 \mathrm{~m}$ altitudes. The fluctuations in the first three levels can be explained with the wide variation of data obtained from the plot areas. Besides that, a significant decrease can be seen in the amount of biomass stored at altitudes higher than $1,500 \mathrm{~m}$. It can be understood that the development of $R$. ponticum populations slows down after reaching this altitude level.

As in altitude levels, we used the analysis of variance to determine if the relevant variables differed by the exposure variable. Accordingly, as seen in table 5, there was 
Table 1. Summarized data from the temporary plots.

Datos resumidos de las parcelas temporales.

\begin{tabular}{|c|c|c|c|c|c|c|c|}
\hline \multirow{2}{*}{ District } & \multirow{2}{*}{ Plots no } & \multirow{2}{*}{$\begin{array}{c}\text { Age } \\
\text { (years) }\end{array}$} & \multicolumn{2}{|c|}{ Coordinates } & \multirow{2}{*}{ Average height (m) } & \multirow{2}{*}{ Altitute (m) } & \multirow{2}{*}{ Exposure } \\
\hline & & & $\mathrm{x}$ & $\mathrm{y}$ & & & \\
\hline \multirow{18}{*}{ Giresun } & 1 & 21 & 466,288 & $4,512,100$ & $2-2.5$ & 900 & $\mathrm{~N}$ \\
\hline & 2 & 19 & 467,038 & $4,512,630$ & $2-2.5$ & 985 & W \\
\hline & 3 & 14 & 469,179 & $4,511,574$ & $2-2.5$ & 500 & $\mathrm{NE}$ \\
\hline & 4 & 21 & 463,484 & $4,506,242$ & $1.5-2$ & 1,400 & $\mathrm{E}$ \\
\hline & 5 & 15 & 463,540 & $4,509,066$ & $1.5-2$ & 1,420 & S \\
\hline & 6 & 16 & 461,265 & $4,494,968$ & $1-1.5$ & 1,700 & S \\
\hline & 7 & 25 & 461,524 & $4,494,589$ & $2.5<$ & 1,550 & SE \\
\hline & 8 & 14 & 467,154 & $4,506,761$ & $1.5-2$ & 850 & SE \\
\hline & 9 & 12 & 472,556 & $4,506,516$ & $1.5-2$ & 1,250 & SE \\
\hline & 10 & 13 & 470,748 & $4,504,499$ & $1.5-2$ & 950 & $\mathrm{NE}$ \\
\hline & 11 & 12 & 469,986 & $4,504,876$ & $1-1.5$ & 880 & $\mathrm{~N}$ \\
\hline & 12 & 21 & 474,493 & $4,514,275$ & $2.5<$ & 970 & $\mathrm{E}$ \\
\hline & 13 & 12 & 470,958 & $4,488,877$ & $1-1.5$ & 1,700 & NW \\
\hline & 14 & 13 & 467,720 & $4,490,991$ & $1-1.5$ & 1,330 & $\mathrm{~N}$ \\
\hline & 15 & 18 & 467,511 & $4,495,709$ & $1-1.5$ & 1,100 & $\mathrm{~N}$ \\
\hline & 16 & 26 & 466,527 & $4,497,502$ & $2.5<$ & 950 & S \\
\hline & 17 & 17 & 466,478 & $4,507,903$ & $2.5<$ & 920 & $\mathrm{~N}$ \\
\hline & 18 & 12 & 470,997 & $4,521,223$ & $2.5<$ & 480 & SW \\
\hline \multirow{18}{*}{ Bartin } & 19 & 13 & 469,441 & $4,601,009$ & $2-2.5$ & 300 & $\mathrm{~N}$ \\
\hline & 20 & 12 & 472,837 & $4,599,478$ & $1.5-2$ & 650 & $\mathrm{~N}$ \\
\hline & 21 & 18 & 459,756 & $4,603,503$ & $2-2.5$ & 220 & $\mathrm{~N}$ \\
\hline & 22 & 12 & 461,832 & $4,590,851$ & $2-2.5$ & 550 & $\mathrm{~N}$ \\
\hline & 23 & 21 & 446,073 & $4,586,621$ & $2-2.5$ & 270 & $\mathrm{SE}$ \\
\hline & 24 & 25 & 443,131 & $4,582,215$ & $2-2.5$ & 220 & $\mathrm{~S}$ \\
\hline & 25 & 11 & 444,300 & $4,577,192$ & $1.5-2$ & 320 & $\mathrm{~N}$ \\
\hline & 26 & 13 & 445,690 & $4,580,133$ & $1.5-2$ & 420 & $\mathrm{~N}$ \\
\hline & 27 & 10 & 458,860 & $4,589,622$ & $1.5-2$ & 240 & $\mathrm{~N}$ \\
\hline & 28 & 11 & 463,771 & $4,590,853$ & $2-2.5$ & 500 & S \\
\hline & 29 & 12 & 469,596 & $4,595,385$ & $1.5-2$ & 530 & $\mathrm{~N}$ \\
\hline & 30 & 15 & 452,822 & $4,585,373$ & $2-2.5$ & 540 & $\mathrm{~N}$ \\
\hline & 31 & 18 & 458,355 & $4,582,833$ & $1.5-2$ & 520 & $\mathrm{NE}$ \\
\hline & 32 & 13 & 456,712 & $4,583,490$ & $1.5-2$ & 415 & $\mathrm{~N}$ \\
\hline & 33 & 20 & 462,489 & $4,595,861$ & $2-2.5$ & 255 & $\mathrm{~N}$ \\
\hline & 34 & 20 & 454,583 & $4,583,689$ & $2-2.5$ & 625 & $\mathrm{~N}$ \\
\hline & 35 & 12 & 451,637 & $4,592,627$ & $2-2.5$ & 620 & $\mathrm{NE}$ \\
\hline & 36 & 25 & 452,400 & $4,592,285$ & $2-2.5$ & 630 & W \\
\hline
\end{tabular}


no significant difference because the $P$ values were found to be higher than 0.05 for wet and/or dry weights of stem, foliage and root. At this point, it can be concluded that the exposure factor has no effect on the biomass development of $R$. ponticum.

Therefore, in total, sunny exposures have higher biomass values than do shadowy exposures. This difference

Table 2. Information about dependent and independent variables used in the analysis of variance.

Información sobre variables dependientes e independientes utilizadas en el análisis de varianza.

\begin{tabular}{|c|c|c|c|}
\hline \multirow{10}{*}{$\begin{array}{c}\text { Independent } \\
\text { variables }\end{array}$} & \multirow{4}{*}{ Altitude levels (m) } & $0-500$ & \multirow{10}{*}{ Categorical } \\
\hline & & $501-1,000$ & \\
\hline & & $1,001-1,500$ & \\
\hline & & $>1,500$ & \\
\hline & \multirow{2}{*}{ Exposure } & Sunny & \\
\hline & & Shadowy & \\
\hline & \multirow{4}{*}{ Height levels (m) } & $1-1.5$ & \\
\hline & & $1.5-2$ & \\
\hline & & $2-2.5$ & \\
\hline & & $>2.5$ & \\
\hline \multirow{3}{*}{$\begin{array}{l}\text { Dependent } \\
\text { variables }\end{array}$} & Stem weight (kg) & \multirow{3}{*}{\multicolumn{2}{|c|}{ Metric }} \\
\hline & Foliage weight $(\mathrm{kg})$ & & \\
\hline & Root weight (kg) & & \\
\hline
\end{tabular}

mainly originates from the difference among stem biomasses. The ratio of belowground biomass to the total biomass was found to be $43 \%$ and $45 \%$, respectively (table 6).

Table 7 presents the results of the analysis of variance performed on the height levels. The $P$ value (SignificancePossibility) was found to be higher than 0.05. Accordingly, it was concluded that there was no statistically significant difference between the wet and/or dry weights of stem, foliage and roots.

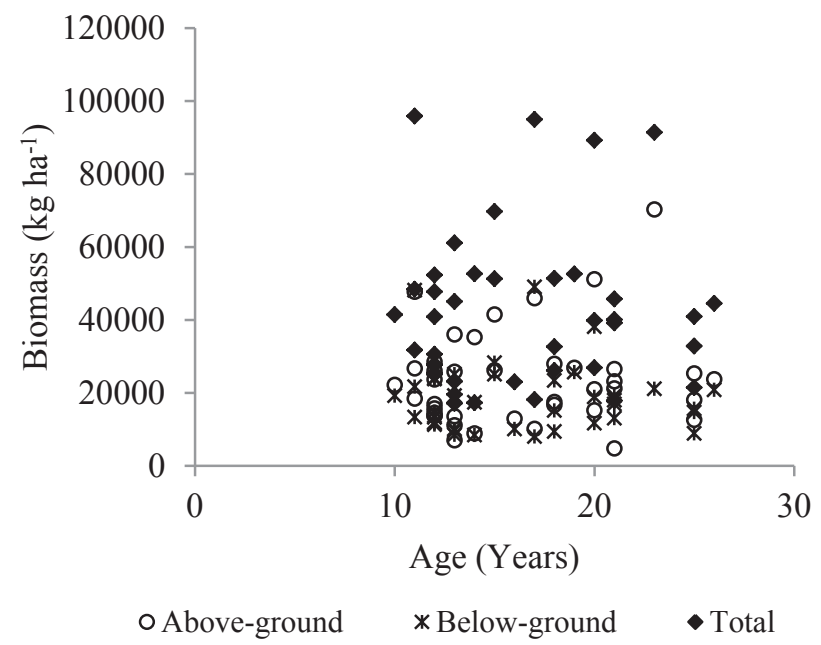

Figure 2. The relationship of mean age with aboveground, belowground, and total amount of biomass.

Relación de la edad promedio con la cantidad de biomasa aérea, subterránea y total.

Table 3. Results of the analysis of variance by altitude levels.

Resultados del análisis de varianza por niveles de altitud.

\begin{tabular}{|c|c|c|c|c|c|c|}
\hline Groups & & $\begin{array}{c}\text { Sum } \\
\text { of squares }\end{array}$ & $\begin{array}{l}\text { Degrees of } \\
\text { freedom }(\mathrm{df})\end{array}$ & $\begin{array}{l}\text { Mean } \\
\text { square }\end{array}$ & $\mathrm{F}$ & $\begin{array}{l}\text { Significance } \\
\quad(P \text {-Sig.) }\end{array}$ \\
\hline \multirow{3}{*}{ Stem weight } & Intergroup & $1.481 \mathrm{E} 8$ & 3 & 4.936E7 & 0.900 & 0.452 \\
\hline & Intragroup & $1.756 \mathrm{E} 9$ & 32 & $5.488 \mathrm{E} 7$ & & (insignificant) \\
\hline & Total & $1.904 \mathrm{E} 9$ & 35 & & & \\
\hline \multirow{3}{*}{ Foliage weight } & Intergroup & $1.066 \mathrm{E} 7$ & 3 & $3,554,164.389$ & 1.508 & 0.231 \\
\hline & Intragroup & $7.543 \mathrm{E} 7$ & 32 & $2,357,235.179$ & & (insignificant) \\
\hline & Total & $8.609 \mathrm{E} 7$ & 35 & & & \\
\hline \multirow{3}{*}{ Root weight } & Intergroup & $5.413 \mathrm{E} 7$ & 3 & $1.804 \mathrm{E} 7$ & 0.512 & 0.677 \\
\hline & Intragroup & $1.128 \mathrm{E} 9$ & 32 & $3.525 \mathrm{E} 7$ & & (insignificant) \\
\hline & Total & $1.182 \mathrm{E} 9$ & 35 & & & \\
\hline \multirow{3}{*}{ Total Weight } & Intergroup & $4.618 \mathrm{E} 8$ & 3 & $1.539 \mathrm{E} 8$ & 0.816 & 0.495 \\
\hline & Intragroup & $6.037 \mathrm{E} 9$ & 32 & $1.877 \mathrm{E} 8$ & & (insignificant) \\
\hline & Total & $6.499 \mathrm{E} 9$ & 35 & & & \\
\hline
\end{tabular}


Total oven-dried $R$. ponticum biomass results are given in table 8 according to vegetation height levels. The ratio of belowground biomass to the total was found to be $42 \%$, $46 \%, 43 \%$ and $43 \%$, respectively. The lowest biomass development was observed in the 1-1.5 m height level. The biomass development in the $>2.5 \mathrm{~m}$ height level confuted the assumption that the biomass increase would peak linearly with the height increase. Contrary to expectation, no linear increase was observed in biomass development.

The biomass data collected from the two regions within the natural distribution area of $R$. ponticum indicated insignificant statistical differences (table 9) between these

Table 4. Mean weights of components by altitude levels.

Pesos medios de componentes por niveles de altitud.

\begin{tabular}{ccccc}
\hline \multirow{2}{*}{ Altitude $(\mathrm{m})$} & \multicolumn{5}{c}{ Mean biomass $\left(\mathrm{kg} \mathrm{ha}^{-1}\right)$} \\
\cline { 2 - 5 } & Stem & Foliage & Root & Total \\
\hline $0-500$ & $18,819 \pm 7,230.2$ & $4,444 \pm 1,532.8$ & $16,773 \pm 4,912.9$ & $40,035 \pm 12,133.3$ \\
$501-1,000$ & $15,136 \pm 8,131.3$ & $3,311 \pm 1,588.2$ & $16,053 \pm 6,466.8$ & $34,500 \pm 15,542.2$ \\
$1,001-1,500$ & $17,740 \pm 6,353.9$ & $3,882 \pm 1,514.0$ & $16,949 \pm 7,489.5$ & $38,571 \pm 13,662.4$ \\
$1,501-$ & $12,580 \pm 3,726.5$ & $2,993 \pm 1,140.5$ & $12,225 \pm 2,326.9$ & $27,798 \pm 4,896.9$ \\
\hline
\end{tabular}

\pm Std. deviation.

Table 5. Variance analysis results by the dominant exposures.

Resultados del análisis de varianza según exposiciones dominantes.

\begin{tabular}{|c|c|c|c|c|c|c|}
\hline Groups & & $\begin{array}{c}\text { Sum } \\
\text { of squares }\end{array}$ & $\begin{array}{c}\text { Degrees of } \\
\text { freedom }(\mathrm{df})\end{array}$ & $\begin{array}{l}\text { Mean } \\
\text { square }\end{array}$ & F & $\begin{array}{l}\text { Significance } \\
\text { (P-Sig.) }\end{array}$ \\
\hline \multirow{3}{*}{ Stem weight } & Intergroup & $5.088 \mathrm{E} 7$ & 1 & $5.088 \mathrm{E} 7$ & & 0.341 \\
\hline & Intragroup & $1.853 \mathrm{E} 9$ & 34 & $5.451 \mathrm{E} 7$ & 0.933 & (insignificant) \\
\hline & Total & $1.904 \mathrm{E} 9$ & 35 & & & \\
\hline \multirow{3}{*}{ Foliage weight } & Intergroup & 41348.642 & 1 & $41,348.642$ & & 0.899 \\
\hline & Intragroup & $8.605 \mathrm{E} 7$ & 34 & $2,530,960.890$ & 0.016 & (insignificant) \\
\hline & Total & $8.609 \mathrm{E} 7$ & 35 & & & \\
\hline \multirow{3}{*}{ Root weight } & Intergroup & $2,071,812.081$ & 1 & $2,071,812.081$ & 0.060 & 0.808 \\
\hline & Intragroup & $1.180 \mathrm{E} 9$ & 34 & $3.471 \mathrm{E} 7$ & & (insignificant) \\
\hline & Total & $1.182 \mathrm{E} 9$ & 35 & & & \\
\hline \multirow{3}{*}{ Total weight } & Intergroup & $7.701 \mathrm{E} 7$ & 1 & $7.701 \mathrm{E} 7$ & 0.408 & 0.527 \\
\hline & Intragroup & $6.422 \mathrm{E} 9$ & 34 & $1.889 \mathrm{E} 8$ & & (insignificant) \\
\hline & Total & $6.499 \mathrm{E} 9$ & 35 & & & \\
\hline
\end{tabular}

Table 6. Mean weights of components by the dominant exposures.

Promedio de los pesos de los componentes según exposiciones dominantes.

\begin{tabular}{ccccc}
\hline Exposure & \multicolumn{4}{c}{ Mean biomass $\left(\mathrm{kg} \mathrm{ha}{ }^{-1}\right)$} \\
Stem & Foliage & Root & Total \\
\hline Sunny & $18,802.3 \pm 6,812^{*}$ & $3,783.9 \pm 1,542.3$ & $16,339 \pm 5,821.2$ & $38,185.6 \pm 12,492.5$ \\
Shady & $15,563.7 \pm 7,715.3$ & $3,714.4 \pm 1,620.3$ & $15,907 \pm 534.3$ & $35,185 \pm 14,464.1$ \\
\hline
\end{tabular}

* Std. deviation. 
Table 7. Results of variance analysis by the height groups.

Resultados de análisis de análisis de varianza por grupos de altura.

\begin{tabular}{|c|c|c|c|c|c|c|}
\hline Groups & & $\begin{array}{c}\text { Sum } \\
\text { of squares }\end{array}$ & $\begin{array}{c}\text { Degrees } \\
\text { of freedom }(\mathrm{df})\end{array}$ & $\begin{array}{l}\text { Mean } \\
\text { square }\end{array}$ & $\mathrm{F}$ & $\begin{array}{l}\text { Significance } \\
\text { (P-Sig.) }\end{array}$ \\
\hline \multirow{3}{*}{ Stem weight } & Intergroup & $1.770 \mathrm{E} 8$ & 3 & $5.900 \mathrm{E} 7$ & \multirow{3}{*}{1.093} & 0.366 \\
\hline & Intragroup & $1.727 \mathrm{E} 9$ & 32 & 5.397E7 & & (insignificant) \\
\hline & Total & $1.904 \mathrm{E} 9$ & 35 & & & \\
\hline \multirow{3}{*}{ Foliage weight } & Intergroup & $2,839,052.415$ & 3 & $946,350.805$ & & 0.780 \\
\hline & Intragroup & $8.325 \mathrm{E} 7$ & 32 & $2,601,717.702$ & 0.364 & (insignificant) \\
\hline & Total & $8.609 \mathrm{E} 7$ & 35 & & & \\
\hline \multirow{3}{*}{ Root weight } & Intergroup & $1.846 \mathrm{E} 8$ & 3 & $6.152 \mathrm{E} 7$ & & 0.138 \\
\hline & Intragroup & $9.976 \mathrm{E} 8$ & 32 & $3.117 \mathrm{E} 7$ & 1.973 & (insignificant) \\
\hline & Total & $1.182 \mathrm{E} 9$ & 35 & & & \\
\hline \multirow{3}{*}{ Total weight } & Intergroup & $7.359 \mathrm{E} 8$ & 3 & $2.453 \mathrm{E} 8$ & 1.362 & 0.272 \\
\hline & Intragroup & $5.763 \mathrm{E} 9$ & 32 & $1.801 \mathrm{E} 8$ & & (insignificant) \\
\hline & Total & $6.499 \mathrm{E} 9$ & 35 & & & \\
\hline
\end{tabular}

Table 8. Mean weights of the components by the height levels.

Pesos medios de los componentes por niveles de altura.

\begin{tabular}{ccccc}
\hline Height $(\mathrm{m})$ & \multicolumn{4}{c}{ Mean biomass $\left(\mathrm{kg} \mathrm{ha}^{-1}\right)$} \\
\hline & Stem & Foliage & Root & Total \\
$1-1.5$ & $11,449 \pm 2,347^{*}$ & $3,230 \pm 859$ & $10,838 \pm 1,672.5$ & $25,517 \pm 2,340,9$ \\
$1.51-2.0$ & $16,594.3 \pm 6,551.7$ & $4,083.6 \pm 1,755.9$ & $17,830 \pm 6,257$ & $38,508.3 \pm 13,767.5$ \\
$2.1-2.5$ & $18,367.6 \pm 9,431.3$ & $3,662.2 \pm 1,187.5$ & $16,790 \pm 5,977.4$ & $38,820.7 \pm 15,748.7$ \\
$2.51-$ & $16,182 \pm 4,377.4$ & $3,653.6 \pm 2,648.4$ & $15,262.8 \pm 4,776.6$ & $35,098.4 \pm 10,394.3$ \\
\hline
\end{tabular}

\pm Std. deviation.

Table 9. Results of analysis of variance by geographic region.

Resultados del análisis de varianza por región geográfica.

\begin{tabular}{|c|c|c|c|c|c|c|}
\hline Groups & & $\begin{array}{c}\text { Sum } \\
\text { of squares }\end{array}$ & $\begin{array}{c}\text { Degrees } \\
\text { of freedom }(\mathrm{df})\end{array}$ & $\begin{array}{l}\text { Mean } \\
\text { square }\end{array}$ & $\mathrm{F}$ & $\begin{array}{l}\text { Significance } \\
(P \text {-Sig. })\end{array}$ \\
\hline \multirow{3}{*}{ Stem weight } & Intergroup & $7.207 \mathrm{E} 7$ & 1 & 7.207E7 & & 0.256 \\
\hline & Intragroup & $1.832 \mathrm{E} 9$ & 34 & $5.389 \mathrm{E} 7$ & 1.337 & (insignificant) \\
\hline & Total & $1.904 \mathrm{E} 9$ & 35 & & & \\
\hline \multirow{3}{*}{ Foliage weight } & Intergroup & $3,886,155.111$ & 1 & $3,886,155.111$ & & 0.213 \\
\hline & Intragroup & $8.221 \mathrm{E} 7$ & 34 & $2,417,878,346$ & 0.607 & (insignificant) \\
\hline & Total & $8.609 \mathrm{E} 7$ & 35 & & & \\
\hline \multirow{3}{*}{ Root weight } & Intergroup & $3.958 \mathrm{E} 7$ & 1 & $3.958 \mathrm{E} 7$ & & 0.285 \\
\hline & Intragroup & $1.143 \mathrm{E} 9$ & 34 & $3.360 \mathrm{E} 7$ & 1.178 & (insignificant) \\
\hline & Total & $1.182 \mathrm{E} 9$ & 35 & & & \\
\hline \multirow{3}{*}{ Total weight } & Intergroup & $2.806 \mathrm{E} 8$ & 1 & $2.806 \mathrm{E} 8$ & & 0.224 \\
\hline & Intragroup & $6.219 \mathrm{E} 9$ & 34 & & 1.534 & (insignificant) \\
\hline & Total & 6.499E9 & 35 & $1.829 \mathrm{E} 8$ & & \\
\hline
\end{tabular}


regions. However, the Bartin region had trend of a higher capacity of biomass storage and this difference occurred especially from the stem biomass (figure 3).

Rhododendron ponticum LDMC ratios were calculated for altitude levels, age and exposures. LDMC varied from $0.33 \mathrm{~g} \mathrm{~g}^{-1}$ to $0.44 \mathrm{~g} \mathrm{~g}^{-1}$ in the Bartin region and $0.20 \mathrm{~g} \mathrm{~g}^{-1}$ to $0.33 \mathrm{~g} \mathrm{~g}^{-1}$ in the Giresun region. Additionally, LDMC varied from $0.25 \mathrm{~g} \mathrm{~g}^{-1}$ to $0.44 \mathrm{~g} \mathrm{~g}^{-1}$ in sunny exposure and $0.20 \mathrm{~g} \mathrm{~g}^{-1}$ to $0.41 \mathrm{~g} \mathrm{~g}^{-1}$ in shadowy exposures. LDMC ratios can be seen in figure 4, according to altitude levels and ages.

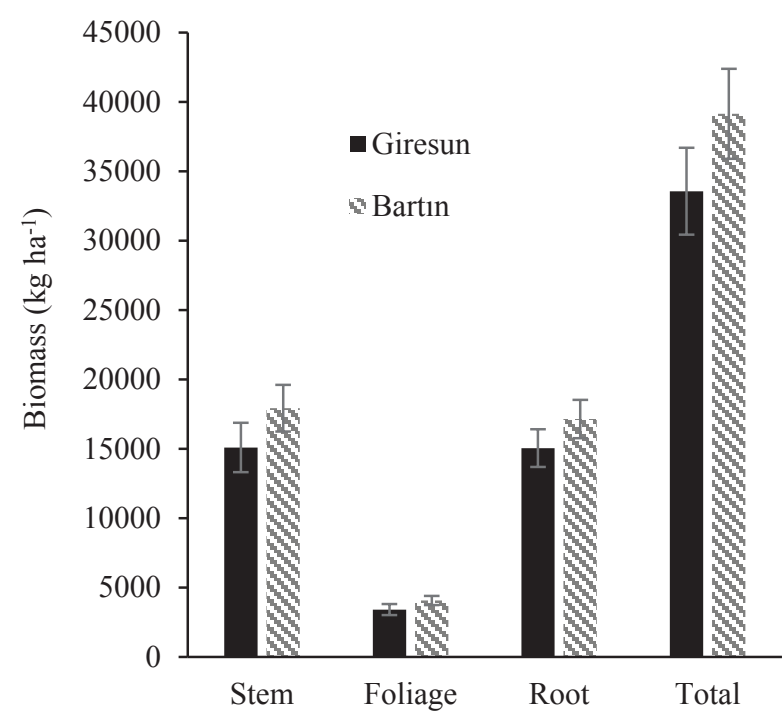

Figure 3. Mean weights (and standard error) of components by the study regions. nes de estudio.

Pesos medios (y error estándar) de componentes según regio-

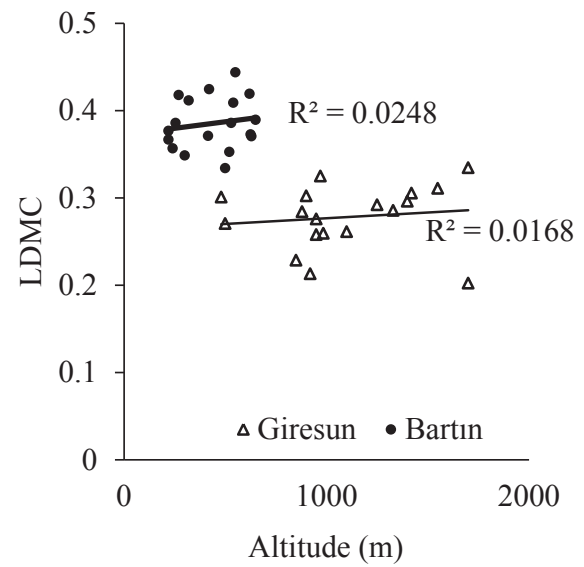

Figure 4. Relationship of LDMC to altitude levels and ages.

Relación de LDMC con niveles de altitud y edades.

\section{DISCUSSION}

In the present study, the aim was to determine the aboveground and belowground biomass of $R$. ponticum in the districts of Giresun and Bartin, both located in the Black Sea region, within its natural distribution. Analyses were performed using the data collected from 36 different plot areas based on different altitude, dominant exposure, mean vegetation height and mean age variables. Moreover, the relationships between the stored biomass and relevant factors were statistically examined. As understood from the findings presented in the results, the biomass values of $R$. ponticum have a very wide variation and no strong statistical relationship with high reliability could be established.

Given the data obtained from 36 plot areas, the mean aboveground biomass amount was calculated to be 23.6 $\mathrm{Mg} \mathrm{ha}^{-1}$. It was also seen that belowground biomass contained approximately $18.4 \mathrm{Mg} \mathrm{ha}^{-1}$ raw root. Mean total biomass was found to be $42 \mathrm{Mg} \mathrm{ha}^{-1}$. According to the results obtained from mean values, the root/shoot ratio was determined to be approximately 0.78 . In a study carried out in Portugal, the root/shoot ratio was found to vary between 3.7 (Arbutus unedo L.) and 0.1 (Cystus multiflorus (L'He'r.)) among Mediterranean woody plants (40 shrubs from 18 species) (Silva and Rego 2004). The shrub biomass containing Rhododendrons spp. was found to be $14.92 \mathrm{Mg} \mathrm{ha}^{-1}$ in the aboveground and $11.46 \mathrm{Mg} \mathrm{ha}^{-1}$ in the belowground in the northeastern Tibetan plateau, with an R/S ratio of 0.86 (Nie et al. 2016). While Rhododendron arboreum stores were $70.41 \mathrm{Mg} \mathrm{ha}^{-1}$ aboveground biomass in Nepal (Ranjitkar et al. 2014), total biomass amount of Rhododendron spp. populations was approximately 40.5 Mg ha-1 in the Central Himalaya Mountains (Garkoti and Singh 1995). As can be seen, the total amount of biomass stored by the community of Rhododendron spp. shows pronounced regional differences. When a regional compa-

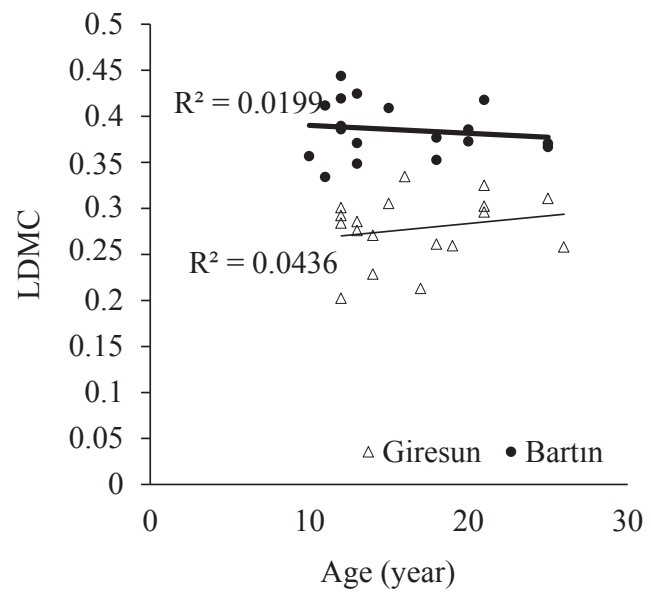


rison is made, Fagus orientalis Lipsky stands, the most common species in the study area stores $272.95 \mathrm{Mg} \mathrm{ha}^{-1}$ biomass for a mean diameter of $40 \mathrm{~cm}$ (Saraçoğlu 1998). It is understood that $R$. ponticum communities store biomass at a rate of $15 \%$ of the Fagus spp. stands.

Only two biomass studies exist that were carried out on the regions where $R$. ponticum occurs as a natural and invasive species. The first study was carried out for individual $R$. ponticum spreading under the Pinus sylvestris L. stands of the Belgian Campine region. According to the results of that study, the total aboveground biomass amount was approximately $7.2 \mathrm{Mg} \mathrm{ha}^{-1}$ and $1 / 3$ of this biomass consisted of foliage biomass (Nadezhdina et al. 2004). Total aboveground biomass equaled $1 / 3$ of the biomass found in the present study.

The second study was a comparison of $R$. ponticum biomass with ecological factors in a local area at an average altitude of $1700 \mathrm{~m}$ in Artvin, Turkey. In this study, the mean aboveground biomass was $16.06 \mathrm{Mg} \mathrm{ha}^{-1}$, belowground biomass was $8.39 \mathrm{Mg} \mathrm{ha}^{-1}$ and total biomass was $24.46 \mathrm{Mg} \mathrm{ha}^{-1}$ for the $R$. ponticum, while root/shoot ratio was found to be 0.52 (Özkaya 2016). These values are similar to our values above $1,500 \mathrm{~m}$. The total average biomass for our study at $1,500 \mathrm{~m}$ and above was $27.79 \mathrm{Mg}$ $\mathrm{ha}^{-1}$. Again, in the present study, the share of foliage in the aboveground biomass was found to be $16 \%$ and $17 \%$ in the Giresun and Bartin regions, respectively. It can be understood that the Rhododendron spp. in the Belgian Campine region have two times more foliage biomass from a proportional aspect. It is reported that $27 \%$ of the aboveground biomass in the Artvin region was leaves, which is $10 \%$ more than in our study (Özkaya 2016). In studies on determining the share of foliage in aboveground biomass of Phillyrea latifolia $\mathrm{L}$., which is a maquis population, Armand et al. (1993) found that it constituted $27 \%$ of the mean aboveground biomass in France. While the same ratio was found to be $15 \%$ in Italy by Marziliano et al. (2015) and $7 \%$ in Croatia by Topic et al. (2009).

Another attention-grabbing result is the portion of belowground raw root biomass to total biomass. Our value varied between $42 \%$ and $47 \%$, while in the Artvin region this ratio was $34.34 \%$ (Özkaya 2016). When compared to the root ratios of forest trees, this seems very high. For instance, Helmisaari et al. (2002) reported this value to be $25.3 \%$ for young stands, $21 \%$ for mid-aged stands and $13.2 \%$ for advanced-aged stands of Yellow Pine. In their study on the individuals of Phillyrea latifolia, which is a shrubby and small-tree-formed species, Marziliano et al. (2015) reported that $9.15 \%$ of total biomass was stored in the foliage, $50.24 \%$ in stem, $59.6 \%$ above the ground and $40.6 \%$ below the ground. Canadel and Roda (1991) reported that, in Quercus ilex L. populations, $72 \%$ of the total biomass consisted of aboveground biomass and the remaining $28 \%$ consisted of the belowground biomass. The results obtained in the present study corroborates the belowground biomass values reported by Marziliano et al. (2015).
Rhododendron ponticum LDMC values showed that there were differences among ratios according to altitude levels and ages. However, there were considerable differences between the regions. While the regions had closer LDMC values within themselves, it is seen that the Bartin region had higher rates than those observed in the Giresun region. The Bartin region also had a higher foliage biomass. This can be explained by the fact that the $R$. ponticum spreads at lower elevations $(220-650 \mathrm{~m})$ in this region. Mean LDMC was $0.40 \mathrm{~g} \mathrm{~g}^{-1}$ in Bartin and $0.29 \mathrm{~g} \mathrm{~g}^{-1}$ in Giresun at sunny exposures. Moreover, at shadowy exposures, mean LDMC was $0.37 \mathrm{~g} \mathrm{~g}^{-1}$ in Bartin and $0.26 \mathrm{~g}$ $\mathrm{g}^{-1}$ in Giresun. Illa et al. (2017) reported that LDMC was lower at shadowy exposures. The LDMC values obtained in the present study are similar to these study results.

As a general assessment, it can be stated that the sunny exposures had higher levels of biomass. Considering the mean vegetation height, it can be concluded that $1.5-2.0 \mathrm{~m}$ and 2.0-2.5 m height levels have similar biomass levels, and between these two groups, the 1-1.5 m height level had $35 \%$ lower biomass, while the $>2.5 \mathrm{~m}$ height level also had lower biomass storage. The reason for this is that $R$. ponticum populations with low mean vegetation heights have thinner and more prolific number of stems per unit area, and higher vegetation height populations have thicker and fewer stems. Considering the variations between the biomass storage capacities at the altitude levels between 0 and $1,500 \mathrm{~m}$, no statistically significant difference was observed, besides the decrease in biomass storage capacity of altitudes higher than $1,500 \mathrm{~m}$. In statistical analyses performed between dominant exposure, altitude and vegetation height levels and mean biomass values, no sufficiently reliable relationship could be established. This is because the data obtained from the plot areas showed a significant variation.

The Rhododendron spp. populations, which generally grow in a relatively shadowy environment under the forest cover, store remarkable amounts of biomass and consequently have high levels of carbon in their aboveground and belowground organs. Fagus orientalis (Lipsky), which is one of the essential forest tree species of the region, contains $120-149 \mathrm{Mg} \mathrm{ha}^{-1}$ biomass compared to 100 -year-old site classes and, for $50 \mathrm{~cm}$ goal diameter, Abies bornmülleriana (Mattf.) stores 223-301 Mg ha ${ }^{-1}$ aboveground biomass (Saraçoğlu 1998, Durkaya et al. 2013). According to the data obtained in the present study, the mean aboveground biomass storage was determined to be $23.6 \mathrm{Mg}$ $\mathrm{ha}^{-1}$. The biomass storage levels of Rhododendron spp. populations, which are under pressure from humans as a fuel source, are attention grabbing.

Nowack and Markgraf (1928) reported that there were no Rhododendron spp. in the moisture-lacking regions of the western Black Sea region, and that it was related to exposure. Besides that, in the present study, it was observed that $R$. ponticum could find sufficient levels of moisture under any point in the Black Sea Mountains, even in 
southern exposures. The mean total biomass amount, even in sunny exposures, was found to be $3,000 \mathrm{~kg} \mathrm{ha}^{-1}$ when compared to shadowy exposures.

\section{CONCLUSIONS}

Although $R$. ponticum has an important distribution throughout the world as a natural and invasive species, the studies on this species are very limited. Moreover, there are no comparable and comprehensive biomass or carbon storage studies on this species, and there are no reliable data, even regarding the area covered by this species in its distribution region.

The hypothesis and design of this research were based on the assumption that there are significant differences in biomass storage capacity in terms of certain vegetation and habitat condition characteristics. However, a mean age-biomass relationship could not be generalized with regression as expected because the related data show high variations. Similarly, there were no statistically significant differences found among the variables of: exposure, altitude, mean height of vegetation and biomass storage capacities of $R$. ponticum components. Moreover, the expectation was that there would be significant differences among mean vegetation height subgroups based on biomass storage capacities, nonetheless this could not be observed. Given these results, it can be stated that using average values for the estimation of biomass storage capacities of $R$. ponticum populations is the most reasonable method to use currently.

The $R$. ponticum populations in our study area serve traditionally as a fuel source, as a source for honey production, as a carbon-sink, to prevent erosion in steep regions and to offer shelter and a habitat for wild life. These utilizations will likely continue, and there will be new research in the future. To ensure the continuance of the existence and functions of $R$. ponticum populations, they should first be recognized as such, and the protection-utilization balance should be maintained using the data collected from the field.

\section{ACKNOWLEDGEMENT}

We would like to thank the University of Bartin for their support with this study, under research project number BAP-2012-1-39.

\section{REFERENCES}

Akgül M, S Korkut, O Çamlıbel, Z Candan, T Akbulut. 2012. Wettability and surface roughness characteristics of medium density fiberboard panels from Rhododendron (Rhododendron ponticum) biomass. Maderas Ciencia y Tecnología 14(2): 185-193.

Aksoy H, H Mayer. 1975. Aufbau und waldbauliche Bedeutung nordwestanatolischer Gebirgswalder (Versuchwald Büyükdüz-Karabük). Centralblatt für das Gesamte Forst- wesen 92(2): 65-105.

Armand D, M Etienne, C Legrand, J Marechal, JC Valette. 1993. Phytovolume, phytomasse et relations structurales chez quelques arbustes méditerranéens [Phytovolume, phytomass and structural relationships of certain Mediterranean shrubs]. Annals of Forest Science 50: 79-89.

Canadell J, F Roda. 1991. Root biomass of Quercus ilex in a montane Mediterranean forest. Canadian Journal of Forest Research 21(12): 1771-1778.

Clay DV, JS Goodall, DG Nelson. 1992. The effect of imazapyr on R. ponticum. Aspects of Applied Biology 29: 287-294.

Çolak AH. 1997. Rhododendron pontificum L.(Mor Çiçekli Ormangülü)'nun Silvikültür Özellikleri Üzerine Araştırmalar. PhD dissertation, İstanbul, Turkey. Institute of Science and Technology, İstanbul University. 181 p.

Cross JR. 1975. Biological flora of the British Isles. Rhododendron ponticum L. Journal of Ecology 63: 345-364.

Cross JR. 1981. The establishment of Rhododendron ponticum in the Killarney oakwoods S. W. Ireland. Journal of Ecology 69: $807-824$

Dehnen-Schmutz K, C Perrings, M Williamson. 2004. Controlling Rhododendron ponticum in the British Isles: an economic analysis. Journal of Environmental Management 70: 323-332.

Durkaya A, B Durkaya, Ş Ulu Say. 2016. Below-and above ground biomass distribution of young Scots pines from plantations and natural stands. Bosque 37(3): 509-518.

Durkaya B, A Durkaya, E Makineci, T Karabürk. 2013. Estimating Above-Ground Biomass and Carbon Stock of Individual Trees in Uneven-Aged Uludag Fir Stands. Fresenius Environmental Bulletin 22(2): 428-434.

Esen D. 2000. Ecology and Control of Rhododendron (Rhododendron ponticum L.) in Turkish Eastern Beech (Fagus orientalis Lipsky) Forests. PhD dissertation. Blacksburg Virginia, USA. Faculty of the Virginia Polytechnic Institute and State University. $112 \mathrm{p}$.

Garkoti SC, SP Singh. 1995. Variation in net primary productivity and biomass of forests in the high mountains of Central Himalaya. Journal of Vegetation Science 6(1): 23-28.

Granstrom K. 2003. Emissions of monoterpenes and VOCs during drying of sawdust in a spouted bed. Forest Products Journal 53(10): 48-55.

Gritten RH. 1995. Rhododendron ponticum and some other invasive plants in the Snowdonia National Park. In Pyšek P, K Prach, M Rejmánek, M Wade eds. Plant invasions: general aspects and special problems. Kostelec nad Černými lesy, Czech Republic. p. 213-219.

Helmisaari HS, K Makkonen, S Kellomaki, E Valtonen, E Malkönen. 2002. Below- and above-ground biomass, production and nitrogen use in Scots pine stands in eastern Finland. Forest Ecology and Management 165(1-3): 317-326.

Illa E, JM Ninot, A Anadon-Rosell, F Oliva. 2017. The role of abiotic and biotic factors in functional structure and processes of alpine subshrub communities. Folia Geobotanica 52(2): 199-215.

Joosten R, J Schumacher, W Christian, A Schulte. 2004. Evaluating tree carbon predictions for beech (Fagus sylvatica L.) in western Germany. Forest Ecology and Management 189: 87-96.

Lei TT, ET Nilsen, SW Semones. 2006. Light environment under Rhododendron maximum thickets and estimated carbon 
gain of regenerating forest tree seedlings. Plant Ecology 184(1): 143-156.

Marziliano PA, R Lafortezza, U Medicamento, L Lorusso, V Giannico, G Colangelo, G Sanesi. 2015. Estimating belowground biomass and root/shoot ratio of Phillyrea latifolia L. in the Mediterranean forest landscapes. Annals of Forest Science 72: 585-593.

Milne RI, RJ Abbott. 2000. Origin and evolution of invasive naturalized material of Rhododendron ponticum L. in the British Isles. Molecular Ecology 9: 541-556

Nadezhdina N, F Tatarinova, R Ceulemans. 2004. Leaf area and biomass of Rhododendron understory in a stand of Scots pine. Forest Ecology and Management 187: 235-246.

Nie X, Y Yang, L Yang, G Zhou. 2016. Above-and belowground biomass allocation in shrub biomes across the northeast Tibetan Plateau. PloS one 11(4), e0154251.

Nowack E, F Markgraf. 1928. Die Grenze zwischen der kolchischen waldvegetation und der hochlandsvegetation im nördlichen Kleinasien. Die Naturwissenschaften 16: 753-757.

Özkaya MS. 2016. Determining above and below ground biomass of Rhododendron ponticum. PhD dissertation. Artvin, Turkey. Institute of Science and Technology, Artvin Çoruh University. $144 \mathrm{p}$.

Pajtik J, B Konopka, M Lukac. 2008. Biomass functions and expansion factors in young Norway spruce (Picea abies [L.] Karst) trees. Forest Ecology and Management 256: 10961103.

Ranjitkar S, NM Sujakhu, R Jati, J Xu, D Schmidt-Vogt. 2014. Yield and household consumption of Rhododendron arboreum as a fuelwood species in Eastern Nepal. Biomass and Bioenergy 61: 245-253.
Rotherham ID. 1983. The ecology of Rhododendron ponticum L. with special reference to its competitive and invasive capabilities. PhD dissertation. Sheffield, United Kingdom. Department of Botany, The University of Sheffield. 277 p.

Saraçoğlu N. 1998. Biomass tables of Beech (Fagus orientalis Lipsky). In Research advances in forest mensuration and growth and yield research. Horsholm, Denmark. Danish Forest and Landscape Research Institute. p. 218-221.

Silva JS, FC Rego. 2004. Root to shoot relationships in Mediterranean woody plants from Central Portugal. Biologia 59 (13): 1-7.

Topić V, L Butorac, G Jelić. 2009. Biomass in strawberry tree coppice forests (Arbutus unedo L.) on Island Brač. Izvorni Znanstveni Članci 133: 5-14.

Vaieretti MV, S Díaz, D Vile, E Garnier. 2007. Two measurement methods of leaf dry matter content produce similar results in a broad range of species. Annals of botany 99(5): 955958.

Varol T, HB Özel. 2015. The Efficiency of Mechanization in Weed Control in Artificial Regeneration of Oriental Beech (Fagus orientalis Lipsky.). World Academy of Science, Engineering and Technology, International Journal of Biological, Biomolecular, Agricultural, Food and Biotechnological Engineering 9(1): 18-21.

Zhang X, M Wang, X Liang. 2009. Quantitative classification and carbon density of the forest vegetation in Lüliang Mountains of China. Plant Ecology 201: 1-9.

Zhang B, X Lu, J Jiang, DL DeAngelis, Z Fu, J Zhang. 2017. Similarity of plant functional traits and aggregation pattern in a subtropical forest. Ecology and Evolution 7(12): 40864098. DOI: 10.1002/ece3.2973 